Januari 2019, Vol. 3 No. 1

Received: Desember 2018

Accepted: Januari 2019

Published: Januari 2019

Article DOI: http://dx.doi.org/10.24903/jam.v3i1.382

\title{
Perancangan dan Implementasi Alat Backwash Air Layak Konsumsi
}

\author{
Erick Sorongan \\ Politeknik Negeri Balikpapan \\ erick.sorongan@poltekba.ac.id \\ Saiful Ghozi \\ Politeknik Negeri Balikpapan \\ saiful.ghozi@potekbal.ac.id \\ Emil Azmanajaya \\ Politeknik Negeri Balikpapan \\ emil.azmanajaya@potekbal.ac.id \\ Hilmansyah \\ Politeknik Negeri Balikpapan \\ hilmansyah@potekbal.ac.id
}

\begin{abstract}
Abstrak
Dampak dari kekurangan air bersih dapat dirasakan secara langsung oleh warga Balikpapan, mulai dari kualitas air yang berbau dan tidak jernih bahkan apabila hal ini terus dibiarkan bisa menyebabkan penyakit menular seperti diare dan tifus. Salah satu metode yang dapat dilakukan untuk mengatasi masalah ketersediaan air bersih layak konsumsi adalah dengan membuat sebuah sistem pencucian air baku atau yang dikenal dengan sebutan backwash. Alat ini dirancang dengan menggabungkan beberapa bahan media yang digunakan untuk filter yang terdiri atas karbon aktif, zeolite, mangan dan pasir silica. Sedangkan proses pemisahan zat berbahaya yang terkandung dalam air baku menggunakan teknik sedimentasi alami sehingga terbebas dari penggunaan bahan kimia. Berdasarkan hasil pengamatan Tim PKM Poltekba di Al Muhajirin, alat ini mampu mengurangi tingkat kandungan mangan dan bakteri yang terbawa dari baku PDAM sehingga ketika ditampung di bak penampungan air sudah siap untuk dikonsumsi. Selain itu juga hasil PKM ini mampu memperpanjang usia media yang dipakai dengan cara penggunaan yang tepat, sehingga kedepan alat ini dapat dikembangkan memiliki kemampuan menghasilkan air bersih yang bisa langsung diminum dari hasil olahan atau treatment lanjutan.
\end{abstract}

Kata Kunci: air bersih, backwash, treatment air 


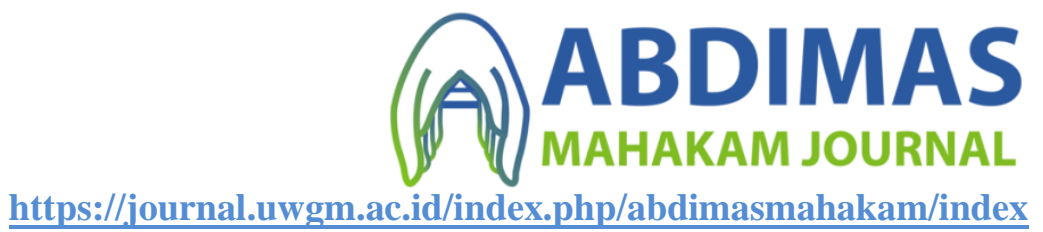

E-ISSN: $2549-5755$

Januari 2019, Vol. 3 No. 1

\section{Pendahuluan}

Lembaga Kesejahteraan Sosial Anak (LKSA) Al Muhajirin adalah salah satu LKSA yang berada di kelurahan Manggar Balikpapan Timur, kota Balikpapan. LKSA ini dihuni oleh anak dengan berbagai latar belakang keluarga sejumlah 64 anak dari mulai usia SD hingga ada yang masuk perguruan tinggi. Dalam aktifitas kesehariannya di lingkungan LKSA, ketersediaan air untuk kebutuhan sehari- hari diperoleh melalui gafilitas PDAM. Sedangkan untuk kebutuhan air minum sejauh ini dipasok dari donatur sebanyak 10 galon per minggu. Secara umum kebutuhan air di LKSA tersebut sudah cukup memenuhi, namun ketergantungan LKSA terhadap pasokan air siap konsumsi oleh donator menjadi permasalahan tersendiri bagi pengurus LKSA.

Jika suatu saat pasokan terhenti, maka LKSA harus menyediakan air siap minum dengan cara membeli, sehingga memberatkan biaya operasional LKSA. Sedangkan kualitas PDAM tidak memungkinkan untuk dimasak karena mengandung zat kapur dan mangan yang cukup tinggi. Menurut peraturan menteri kesehatan (Menkes, 1990) kualitas air yang memiliki kandungan Fe dan mangan yang cukup tinggi secara kualitas belum layak untuk dikonsumsi oleh manusia (Menkes, 2002). Apabila dibandingkan pada skala industri kandungan $\mathrm{Fe}$ dan mangan umumnya diturunkan dengan penambahan oksigen kedalam air sampai dengan $\mathrm{pH}>7$ (Benefield, 1990). Untuk itu diperlukan upaya membangun kemandirian LKSA dalam menghasilkan air layak konsumsi agar air yang ditampung dapat layak untuk digunakan dalam menunjang kebutuhan primer (seperti minum dan memasak).

Kegiatan pengabdian kepada masyarakat yang dilakukan ini adalah upaya membangun kemandirian LKSA Al Mujarin dalam menyediakan air siap konsumsi melalui penerapan alat pengolah air yang menghasilkan air yang siap konsumsi. Selain perancangan dan penerapan alat pengolah air, kegiatan pengabdian juga memberikan edukasi kepada anak usia sekolah penghuni panti asuhan dan pengurus panti asuhan untuk senantiasa peduli dengan kualitas air yang dikonsumsi. Sehingga meningkatkan taraf kualitas budaya hidup sehat dilingkungan panti asuhan.

Kualitas air yang baik adalah jernih (bening) dan tidak keruh. Batas maksimal kekeruhan airlayak minum menurut PERMENKES RI Nomor 907 Tahun 2002 adalah 5 skala NTU. Kekeruhan air disebabkan oleh partikel-partikel yang tersuspensi di dalam air yang menyebabkan air terlihat keruh, kotor, bahkan berlumpur. Bahan - bahan yang menyebabkan air keruh antara lain tanah liat, pasir, dan lumpur. Air keruh bukan berarti tidak dapat diminum atau berbahaya bagi kesehatan. Namun, dari segi estetika, air keruh tidak layak atau tidak wajar untuk diminum. Berdasarkan hasil penelitian yang pernah dilakukan agar dapat menyaring kandungan berbahaya pada air bisa dengan menggunakan zeolite asal Bayah yang dihaluskan menjadi butiran-butiran kecil berdiameter $3 \mathrm{~mm}$ dan mampu menurunkan Fe sebesar 55\% dan $40 \%$ Mn dalam air tanah (Rahman, 2004). Sehingga cara ini cukup efektif untuk mengurangi kandungan Fe dan Mn pada air.

Metode yang digunakan dalam mengolah bahan baku air bersih sehingga layak digunakan untuk kebutuhan sehari - hari adalah dengan membuat suatu sistem penyaringan air secara bertahap dan berkelanjutan dimana mulai dari proses sendimentasi dengan sistem saringan 
pasir zeolite yang efektif untuk menghilangkan kandungan mangan dan lapisan atas berminyak didalam air. Selanjutnya air baku akan melewati 5 kali proses filtrasi menggunakan cartridge sendimen air berukuran mulai dari 0,5 micron sampai dengan 0,1 micron. Proses pengolahan bahan baku air ini dilakukan secara fisika tanpa menggunakan bahan kimia sehingga aman untuk digunakan.

\section{Metode}

Langkah - langkah yang dilaksanakan dalam kegiatan pengabdian kepada masyarakat ini secara umum tergambar dalam bagan berikut.

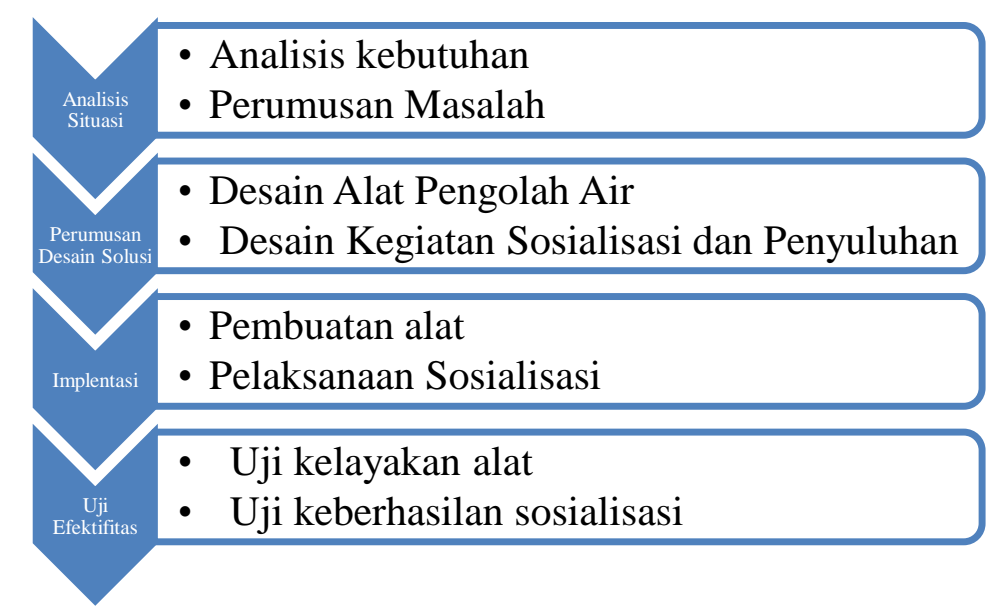

Gambar 1. Bagan Kegiatan Pengabdian kepada Masyarakat

\section{Hasil dan Pembahasan \\ Teknik Pengolahan Bahan Baku Air PDAM di LKSA Al Muhajirin}

a. Sendimentasi

Sedimentasi adalah pemisahan partikel dari air dengan memanfaatkan gaya gravitasi.

Proses ini terutama bertujuan untuk memperoleh air buangan yang jernih. Dalam proses sedimentasi hanya partikel- partikel yang lebih berat dari air yang dapat terpisah. Misalnya kerikil dan pasir, padatan pada tangki pengendapan primer, Biofloc pada tangki pengendapan sekunder, floc hasil pengolahan secara kimia dan lumpur (pada pengendapan lumpur). Didalam sistem pengolahan ini proses pengolahan yang utama adalah penyaringan dengan media pasir dengan kecepatan penyaringan yang lambat (kisaran 5$10 \mathrm{~m} 3 / \mathrm{m} 2 /$ hari). Jika air baku dialirkan ke saringan pasir lambat, maka kotoran-kotoran yang ada didalamnya akan tertahan pada media pasir (Said, 1999).

b. Filtrasi

Filtrasi atau penyaringan (filtration) adalah pemisahan partikel zat padat dari fluida dengan jalan melewatkan fluida itu melalui suatu medium penyaring atau septum, dimana zat padat itu tertahan. Dalam industri, filtrasi ini meliputi ragam operasi mulai dari penapisan sederhana sampai separasi yang sangat rumit. Carbon filter adalah karbon aktif sebagai sarana proses filterisasi dengan tujuan mengadakan penyaringan untuk jenis-jenis 


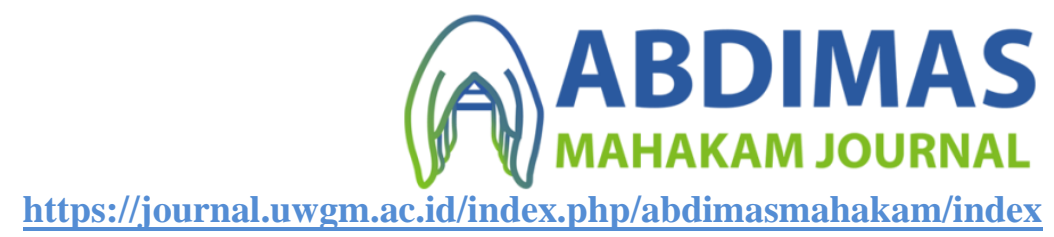

E-ISSN: 2549-5755

Januari 2019, Vol. 3 No. 1

material yang terdapat dalam air, seperti bau, kekeruhan, serta warna-warna yang mungkin timbul pada air baku dan menyaring kotoran dengan ukuran antara $1 \mathrm{~s} / \mathrm{d} 2 \mathrm{~mm}$. Alat yang dirancang menggunakan media carbon aktif, pasir silica dan zeolite.

Proses awal yang yang dilakukan dalam membuat alat backwash ini adalah dengan membuat desain atau rancangan yang tampak seperti pada Gambar 1 sebagai berikut.

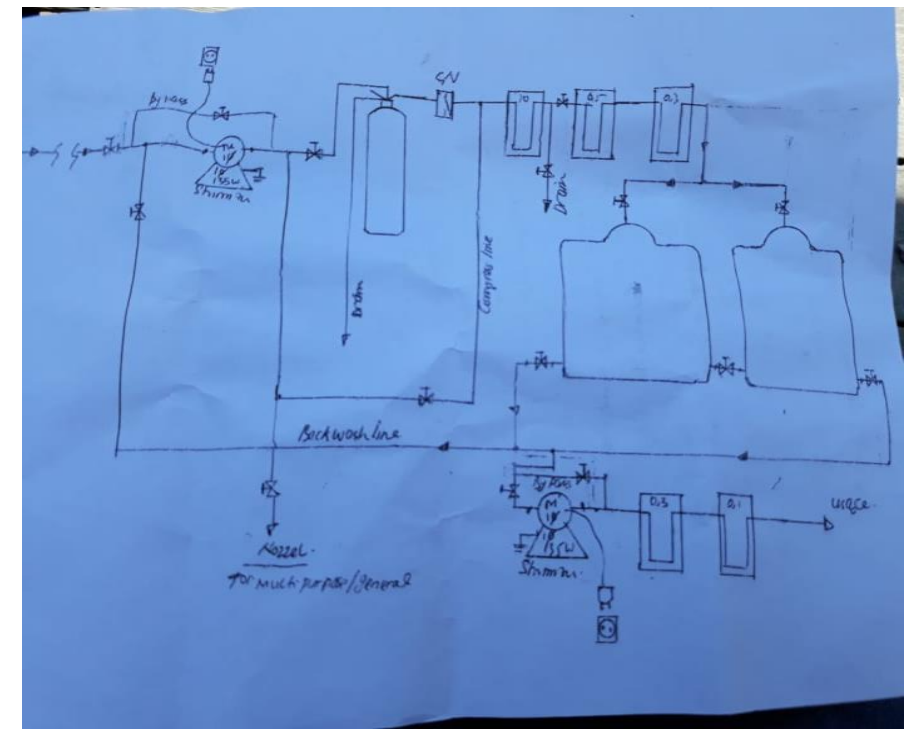

Gambar 1. Rancangan Backwash Air

Adapun proses kerja dari instalasi treatment penjernih air yang akan dibuat sebagai berikut :

1. Mesin pompa digunakan untuk mengalirkan air PDAM yang keruh, kemudian air dilewatkan melalui saringan pasir cepat selanjutnya masuk ke saringan pasir lambat ( $U p$ Flow) (seperti terlihat pada urutan panah kedua). Penyaringan air dengan pasir bertujuan sebagai treatment pendahuluan sekaligus mengurangi kandungan Mangan (Mn), zat besi dan zat-zat menimbulkan bau. Sistem semacam ini sangat efektif, karena ketika bahan baku dialirkan ke saringan pasir lambat, kotoran-kotoran didalamnya akan tertahan pada media pasir tanpa harus memakai zat kimia (Said, 1999).

2. Tahap selanjutnya adalah proses filtrasi (carbon actived), memakai tabung filter berbahan dasar karbon aktif. Digunakan sebagai adsorben untuk menghilangkan warna, pengolahan limbah, serta pemurnian air. Karbon aktif akan membentuk amorf yang sebagian besar terdiri dari karbon bebas dan memiliki permukaan dalam yang berongga, warna hitam, tidak berbau, tidak berasa, dan mempunyai daya serap yang jauh lebih besar dibandingkan dengan karbon yang belum menjalani proses aktivasi (Noerhadi, 2017). Dengan kata lain proses ini bertujuan untuk menghilangkan kotoran-kotoran air yang masih terkandung dalam air. Biasanya proses ini menggunakan bahan sand filter yang disesuaikan dengan kebutuhan baik debit maupun kualitas air dengan media filter.

3. Air yang melewati karbon aktif selanjutnya dilewatkan pada proses sendimentasi, yang mana dalam proses ini diwakili dengan cartride berukuran 1,0 micron diteruskan cartridge ukuran 0,5 micron dan 0,3 micron sampai dengan masuk kedalam 2 bak penampungan. 


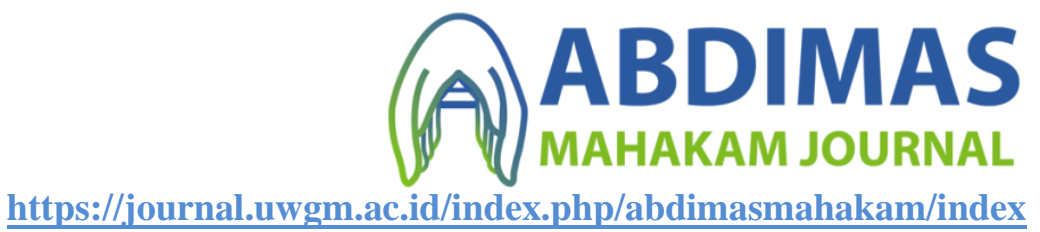

E-ISSN: 2549-5755

Januari 2019, Vol. 3 No. 1

4. Proses akhir dari treatment air ini adalah mengalirkannya kedalam bak penyimpanan yang berukuran cukup besar, dengan hasil output bahan baku air telah jernih, bebas dari kandunga Fe dan Mn serta E. Coli. Produk ini dihasilkan dari proses sedimentasi akhir menggunakan cartridge berukurab 0,3 micron dan 0,1 micron sampai pada akhirnya bisa digunakan sebagai air yang layak konsumsi.

Implementasi alat di lapangan sedikit berbeda dari rancangan yang dibuat pada metode pelaksanaan, hal ini dikarenakan penyesuaian kondisi di Muhajirin dan anggaran yang dimiliki oleh Tim. Seperti tampak pada Gambar 1 diatas proses dimulai ketika air bahan baku PDAM dialiri melalui pipa dengan bantuan pompa penyedot air untuk memaksimalkan kuantitas air yang dialiri. Tahap penyaringan awal dilakukan pada tabung filter yang berisi media diantaranya, karbon aktif, zeolite mangan dan pasir silica. Tujuannya adalah untuk mengurangi kadar klorin yang terdapat pada bahan baku air PDAM, dimana kandungan ini berbahaya bagi manusia jika terlalu berlebihan dan bisa mempengaruhi sistem kekebalan tubuh manusia. Setelah proses filter pertama selesai langkah berikutnya adalah :

1. Penyaringan menggunakan cartridge 0,5 micron yang memiliki bahan terbuat khusus yang membunuh polutan dalam air seperti kuman, bakteri, virus dan micro organisme lainnya yang berbahaya bagi tubuh

2. Penyaringan menggunakan cartridge 0,3 micron yang berfungsi untuk menyaring atau memfilter air dari kandungan lumpur, pasir, tanah dan partikel kotoran zat padat terlarut air lainnya sehingga menghasilkan air jernih bebas dari pencemaran zat padat terlarut dalam air baku PDAM.

3. Air yang telah difilter menggunakan cartridge ukuran 0,5 dan 0,3 selanjutnya akan ditampung kedalam 2(dua) buah bak penampungan dengan dibantu melalui pipa air. Air yang ditampung pada bak penampungan sebenarnya telah siap untuk digunakan untuk masak, mandi, minum dan lain-lain. Namun karena alat ini ditekankan lebih kepada proses backwash air produk, maka proses berikutnya adalah mencuci ulang atau kembali alat menggunakan air produk yang siap konsumsi tersebut dengan mengulangi langkah filterisasi awal sampai dengan tahap nomor. 2

4. Langkah keempat adalah memfilter air menggunakan cartridge ukuran 0,3 micron dan 0,1 micron yang bertujuan untuk memastikan bahwa air produk dari tempat penampungan benar-benar terbebas dari kandungan berbahaya untuk selanjutnya dialiri kepada pengguna untuk dikonsumsi. 


\section{(A) ABDIMAS}

https://journal.uwgm.ac.id/index.php/abdimasmahakam/index

E-ISSN: 2549-5755

Januari 2019, Vol. 3 No. 1

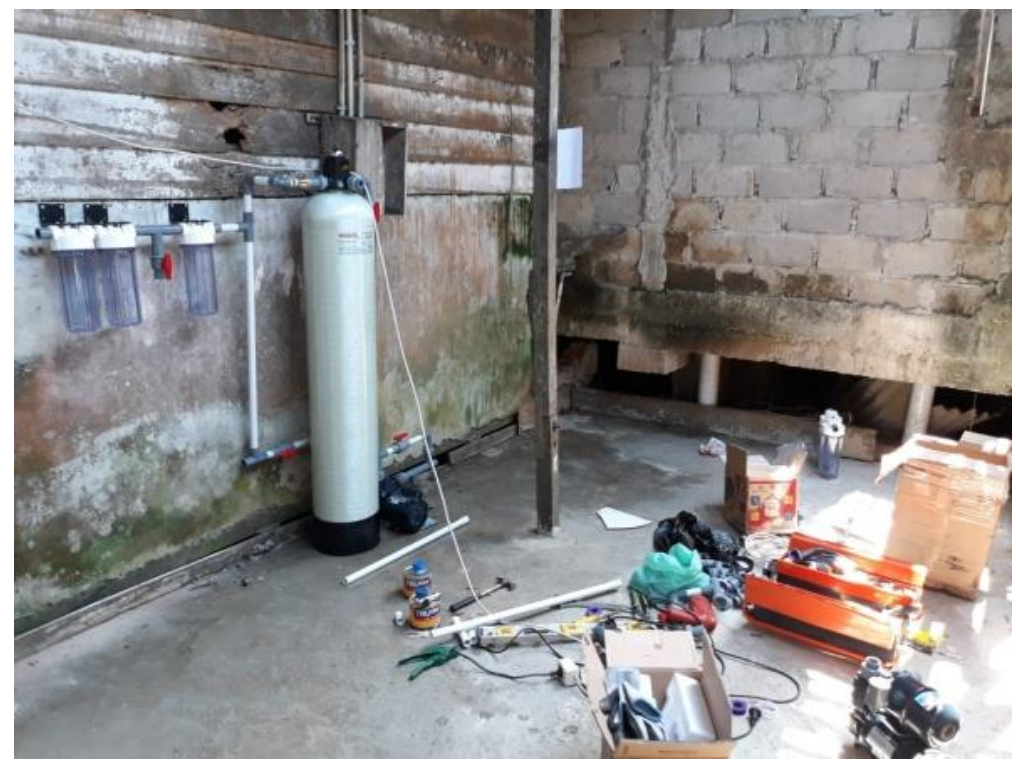

Gambar 2. Proses Perakitan Alat Backwash Air

Pada Gambar 2 adalah proses perakitan alat sesuai dengan dengan atau rancangan. Proses ini membutuhkan waktu sekitar 1 minggu untuk benar-benar berfungsi. Alat ini juga memiliki kemampuan untuk mencuci media yang digunakan dengan memanfaatkan bahan produk (air siap konsumsi) sehingga menurunkan biaya perawatan yang cukup signifikan, terutama dalam hal penggunaan media. Cara ini dilakukan dengan menutup beberapa titik keran yang bersumber dari PDAM untuk selanjutnya dilakukan proses pencucian media dan filter air menggunakan air produk. Cara ini dirasa sangat efektif dan dapat memperpanjang umur dari media yang digunakan, sehingga menghemat pengeluaran untuk dimasa berikutnya. Cara seperti ini juga sebetulnya masih sedikit dilakukan oleh pemilik perusahaan maupun pengelola air minum, yang biasanya mencuci media atau filter dengan menggunakan bahan baku (baik berasal dari sumur maupun PDAM) dimana hal tersebut justru membuat masa pakai media akan lebih cepat using atau kotor. Pencucian media menggunakan air produk akan meningkatkan kualitas dari air tersebut ketika nantinya akan dilakukan tahap berikutnya dalam menampung air hasil olahan di bak penampungan. 


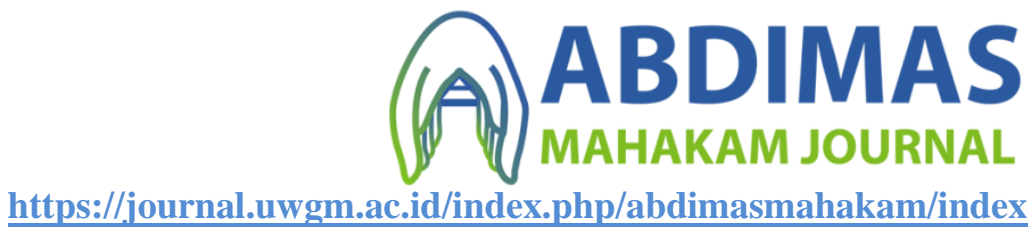

E-ISSN: 2549-5755

Januari 2019, Vol. 3 No. 1

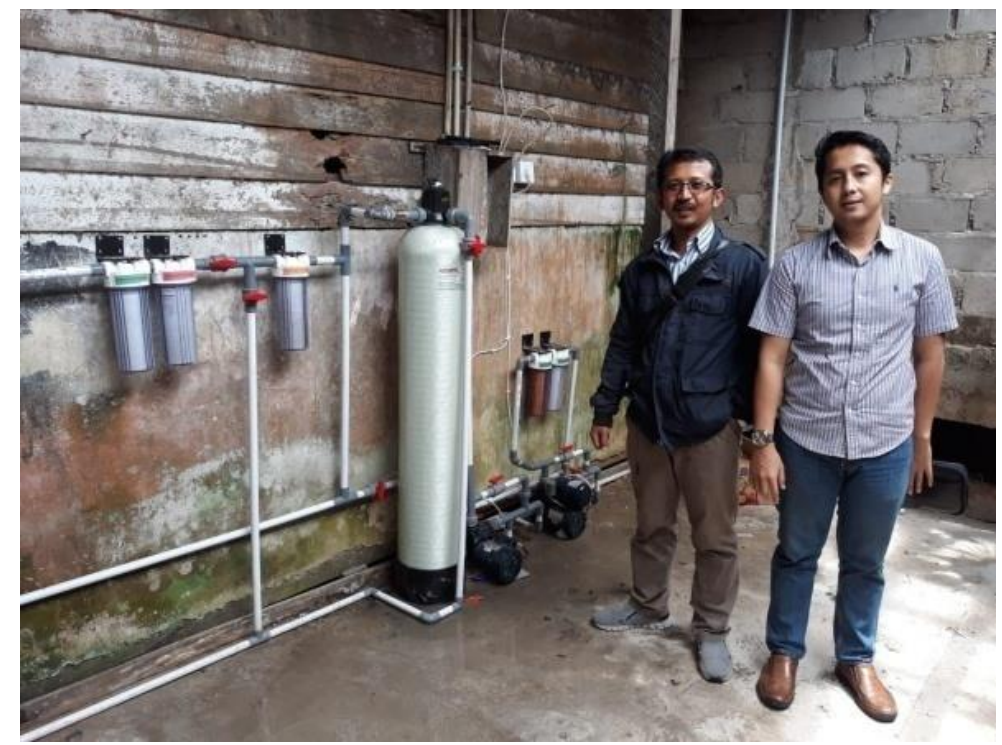

Gambar 3. Alat Backwash Air Layak Konsumsi

Pada Gambar 3 adalah hasil dari pengimplementasian alat di Panti Asuhan Muhajirin Sepinggan Balikpapan. Alat ini sangat membantu bagi penghuni Panti Asuhan dalam mengkonsumsi air yang dipastikan layak untuk konsumsi, tidak hanya berbekal dari air yang dipasok dari PDAM dengan kandungan zat berbahaya yang ada didalamya. Sebuah hasil penelitian menunjukkan bahwa kualitas air Waduk Manggar belum memenuhi syarat menjadi sumber air bersih, begitu pula dengan air di instalasi pengolahan dan air kran pelanggan karena masih terdapat parameter kualitas air yang belum sesuai dengan baku mutu air bersih dan minum (Vaniandayani, 2010) sehingga alat ini sangat membantu masyarakat khususnya di LKSA dalam mendapatkan air kualitas layak konsumsi.

\section{Sosialisasi dan Pembiasaan Hidup Anak LKSA}

Kegiatan berikutnya setelah perancangan dan pengimplementasian alat backwash air adalah melakukan edukasi kepada penghuni LKSA akan pentingnya pola hidup sehat. Ada 4 faktor yang berpengaruh terhadap status kesehatan derajat masyarakat atau individu, antara lain : (a) keturunan, (b) lingkungan, (c) perilaku dan (d) pelayanan kesehatan (Blum, 1995). Pada Gambar 4. menunjukkan kegiatan penyuluhan akan pentingnya perilaku hidup sehat mengingat mayoritas penghuni di LKSA $85 \%$ usia balita dan remaja dan $15 \%$ diantaranya lanjut usia. Apabila mereka tidak peduli akan perilaku pola hidup sehat maka akan rentan sekali terserang penyakit menular, seperti tuberculosis, ISPA, diare, demam berdarah dan penyakit kulit lainnya. Pentingnya edukasi perilaku hidup sehat adalah penyakit terkait air, sanitasi dan higienis menyumbangkan 3,5 persen dari total kematian di Indonesia menurut laporan WHO pada Tahun 2008. Sementara Riskesdas 2007 menyebutkan, diare menjadi penyebab kematian pertama balita dengan kisaran 25 persen (Kania, 2015). 


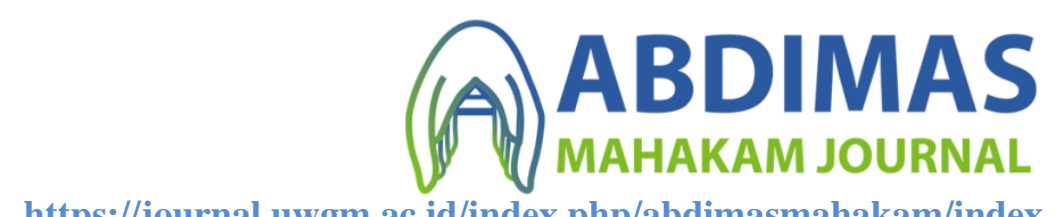

https://journal.uwgm.ac.id/index.php/abdimasmahakam/index

E-ISSN: 2549-5755

Januari 2019, Vol. 3 No. 1

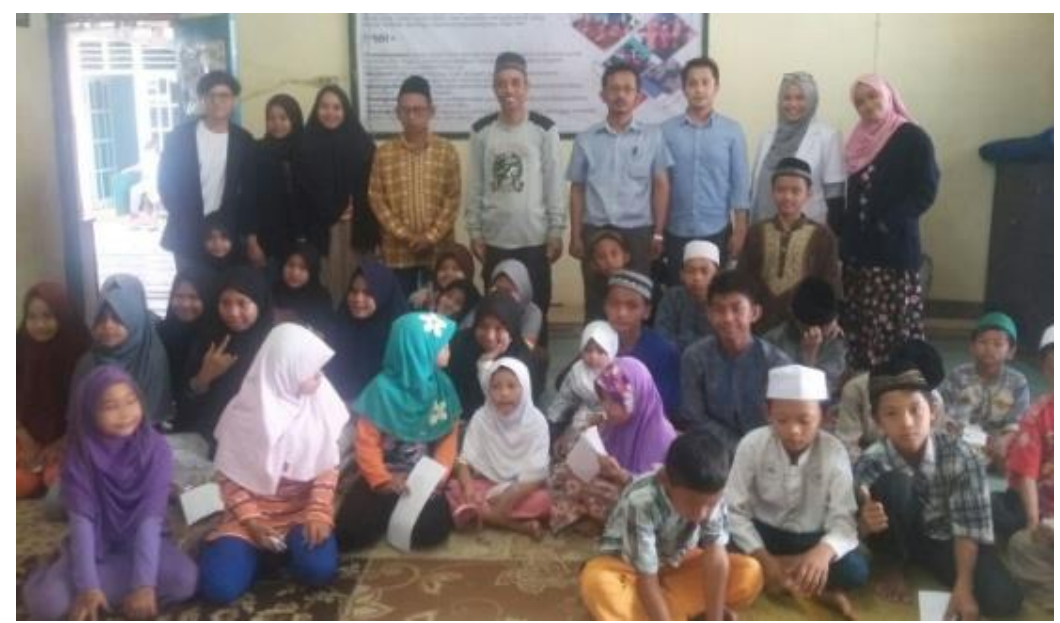

Gambar 4 Sosialisasi Perilaku Hidup Bersih dan Sehat (PHBS)

\section{Simpulan dan rekomendasi}

1. Hasil PKM alat backwash air ini sangat berguna bagi penghuni di Al Muhajirin dalam menjamin ketersediaan air bersih layak konsumsi di bak penampungan yang dimiliki. Hal ini sangat membantu ketika Waduk Manggar Balikpapan sedang mengalami kekeringan melalui air hasil olahan menggunakan alat backwash yang diinstal. Selain itu juga alat ini memiliki kemampuan dalam menjaga masa pakai media yang digunakan sehingga termasuk ketika bahan baku berasal dari sumber lainnya seperti air hujan. Selain itu kegiatan PKM ini merupakan bentuk kepedulian terhadap perilaku hidup sehat melalui pemanfaatan air layak konsumsi.

2. Kedepan untuk memaksimalkan alat backwash air yang diimplementasikan sangat diperlukan peningkatan sistem pengolahan air yang ada saat ini, sehingga mampu menghasilkan air yang siap minum dari bak penampungan dan bisa menjadi income generate bagi Al-Muhajirin. 


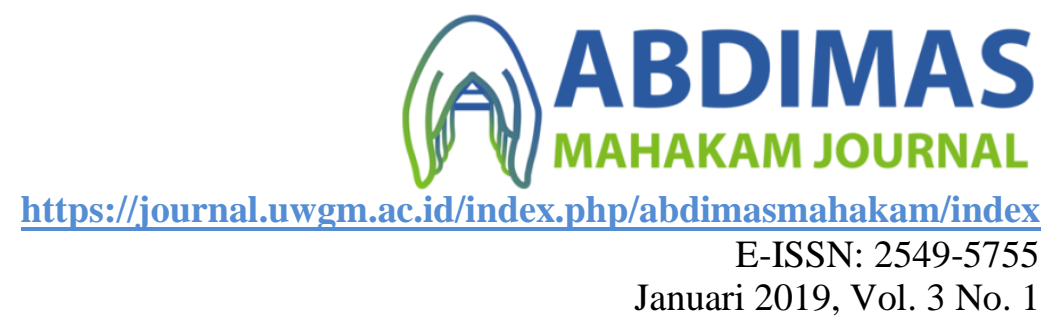

\section{Daftar Pustaka}

Benefield LD. (1990). Morgan JS. Chemical precipitation. In: Pontius FW, editor. Water Quality and Treatmen. A Handbook of Community Water Supplies. 4th ed. New York: McGraw-Hill, 641-708.

Blum, H. et.al. (1995). Public Health Informatics : How Information-Age Technology can Strenthen Public Health, Annu. Rev. Public Health 16: 239-52.

Departemen Kesehatan RI. (2002) Keputusan Menteri Kesehatan RI No. 907/MenKes/SK/VII/2002. Jakarta: Departemen Kesehatan RI.

Departemen Kesehatan RI, (1990). Peraturan Menteri Kesehatan RI No. 416/MenKes/Per/IX/1990. Jakarta: Departemen Kesehatan RI.

Kania, D. (2015). Penyakit Akibat Air Kotor dan Sanitasi Buruk. Okezone. Retrieved from https://lifestyle.okezone.com/read/2015/10/15/481/1232392/penyakit-akibat-air-kotordan-sanitasi-buruk

Noerhadi Wiyono, Arief Faturrahman, I. S. (2017). Sistem pengolahan air minum sederhana (portable water treatment). Konvesi, 6(1), 27-35.

Rahman, A. Hartono, B. (2004). Penyaringan Air Tanah dengan Zeolit Alami untuk Menurunkan Kadar Besi dan Mangan. Makara, Kesehatan. Vol.8 N0.1: 1-6.

Said, N. I. (1999). Teknologi Pengolahan Air Bersih Dengan Proses Saringan Pasir Lambat “ Up Flow ."

Vaniandayani, N. (2010). Analisis Kualitas Air PDAM Tirta Manggar Kota Balikpapan. Universitas Gadjah Mada. 